\title{
Nerve Cell Differentiation in Hydra Requires Two Signals
}

\author{
Thomas Holstein, ${ }^{*}$ Chica H. Schaller, $†$ and Charles N. David* \\ *Department of Zoology, University of Munich, Luisenstrasse 14, D-8000 Munich 2, West Germany, and $\dagger$ Max-Planck-Institute for Medical \\ Research, Department of Biophysics, Jahnstrasse 29, D-6900 Heidelberg, Federal Republic of Germany \\ Received February 15, 1985; accepted in revised form November 14, 1985
}

\begin{abstract}
Endogenous signals controlling nerve cell commitment in hydra were investigated using an assay for committed nerve precursors. Extracts of hydra tissue were prepared and tested for their ability to induce nerve cell commitment. The active component in such extracts was identified as a neuropeptide, the head activator $[\mathrm{H}$. $\mathrm{C}$. Schaller and $\mathrm{H}$. Bodenmüller (1981) Proc. Natl. Acad. Sci. USA 78, 7000-7004], based on its chromatographic properties and reaction with anti-head activator antibody. In addition, synthetic head activator $\left(10^{-13}-10^{-11} M\right)$ was shown to cause nerve cell commitment. Additional experiments demonstrated that committed nerve precursors require a second signal to differentiate nerve cells. Committed precursors induced by treatment of hydra with head activator do not differentiate in whole hydra; but do differentiate when pieces of treated tissue are explanted or when whole animals are simply injured with transverse cuts. The injury stimulus is long-lived. It cannot be replaced with head activator $\left(10^{-12}-10^{-10} \mathrm{M}\right)$ but is contained in a methanol extract of hydra tissue. (c) 1986 Academic Press, Inc.
\end{abstract}

\section{INTRODUCTION}

In hydra differentiation of nerve cells and nematocytes occurs continuously from a population of multipotent stem cells. These cells are uniformly distributed along the body column and can give rise to either nerve or nematocyte differentiation (for review see Bode and David, 1978). Commitment of stem cells to the nerve pathway occurs in the $\mathrm{S}$ phase of the stem cell cycle; committed cells complete the cell cycle and divide to yield differentiated nerve cells (Berking, 1979; Venugopal and David, 1981b; Yaross et al., 1982).

The pattern of nerve and nematocyte differentiation is not uniform throughout the body column: nerve differentiation occurs primarily in head and foot tissue whereas nematocyte differentiation occurs exclusively in the gastric region (David and Gierer, 1974; David and Challoner, 1974). Head and foot are morphogenetically "dominant" regions and it therefore seems likely that signals controlling tissue morphogenesis may also control stem cell differentiation.

In order to understand the nature of this control, it is necessary to identify the signals which cause nerve cell differentiation. Several years ago Schaller $(1976 a, b)$ initiated experiments of this sort. Her results indicated that extracts of hydra tissue containing morphogenetically active substances could, under some conditions, enhance nerve cell differentiation during head regeneration and in whole animals. The effects were generally small, however, for reasons which have subsequently become clear (see Discussion). The present experiments represent a continuation of Schaller's original investigation with the benefit of better assay techniques and purification procedures which have recently become available.

In the present experiments nerve cell commitment was assayed using an explantation technique in which small pieces of tissue were isolated from hydra and incubated under conditions permitting differentiation of committed cells; uncommitted cells do not differentiate under these conditions (Venugopal and David, 1981a). To identify signals causing nerve commitment, hydra were treated with crude extracts or partially purified extracts of hydra tissue prior to assaying nerve commitment by the explantation procedure.

The principal findings of the present report are that (1) nerve cell commitment can be induced by extracts of hydra tissue and (2) the active substance in extracts is the "head activator," a neuropeptide which stimulates head differentiation in hydra (Schaller, 1973). In the course of these experiments we also observed that committed nerve precursors require a second signal to complete differentiation: nerve differentiation does not occur following treatment with hydra extracts unless the tissue is explanted. Additional experiments indicate that explantation can be replaced by simply injuring the tissue. The molecular nature of the injury signal is not known.

\section{MATERIALS AND METHODS}

Culture conditions and standard hydra. Hydra attenuata were cultured in a modified Loomis and Lenhoff (1956) medium containing $1 \mathrm{~m} M \mathrm{CaCl}_{2}, 0.1 \mathrm{mM} \mathrm{MgCl}_{2}$, $0.1 \mathrm{mM} \mathrm{KCl}$, and $1 \mathrm{mM} \mathrm{NaHCO}$ in deionized water, adjusted to $\mathrm{pH} 7.8$ with $\mathrm{HCl}$. The culture and all the ex- 
periments were carried out at $18 \pm 1^{\circ} \mathrm{C}$. Cultures were fed daily with freshly hatched Artemia nauplii and washed 6-8 hr later.

Budless hydra were used in all experiments. Animals were selected from the culture $22 \mathrm{hr}$ after the last feeding. Such animals contain about 9000 epithelial cells and about 40,000 total cells.

Identification of cell types by maceration. The identification and quantitation of cell types (David, 1973) were performed using a modified maceration solution (acetic acid:glycerin:water $=1: 1: 7)$. Ten to twenty explants were macerated $\left(30-60 \mathrm{~min}, 30^{\circ} \mathrm{C}\right)$ and fixed in about $0.15 \mathrm{ml}$, $5-10$ whole animals in about $0.25 \mathrm{ml}$ total volume (exact volume was determined by weighing); $50 \mu \mathrm{l}$ of the wellmixed cell suspension and $2 \mu \mathrm{l}$ of a $1 \%$ Tween solution were spread over an area of about $1 \mathrm{~cm}^{2}$ on a gelatincoated microscopic slide. Counts were done using a Zeiss phase-contrast microscope with Plan-Neofluar objectives $(25 / 0.8,40 / 0.75)$ on several complete passes across the spread and the concentration of nerve and epithelial cells was then calculated in the original suspension. To compare cell numbers between samples we normalized all cell numbers to the number of epithelial cells (ectodermal and endodermal epithelial cells), which is a convenient measure of piece size. From 100 to 300 nerve cells and 700 to 3000 epithelial cells were counted in a given sample.

Labeling with $\left[{ }^{3} H\right]$ thymidine and autoradiography. Hydra were labeled with $\left[\right.$ methyl $\left.{ }^{3} \mathrm{H}\right]$ thymidine $(44 \mathrm{Ci} /$ mmole; Amersham Buchler, Braunschweig) by injecting the isotope into the gastric cavity using a polyethylene needle (David and Campbell, 1972). Animals were injected with $0.2-0.5 \mu \mathrm{l}$ of the isotope solution at a concentration of 25 or $50 \mu \mathrm{Ci} / \mathrm{ml}$. Under these conditions essentially all injected isotope was incorporated within 30 to $60 \mathrm{~min}$.

Gelatin-coated slides with dried macerations were dipped in autoradiographic emulsion (Kodak NTB 2), exposed 10 days at $4^{\circ} \mathrm{C}$, developed in Kodak D-19 developer $\left(6 \mathrm{~min}\right.$ at $\left.21^{\circ} \mathrm{C}\right)$, rinsed in Ektaflo stop-bath, fixed in Ektaflo fixing-bath, and washed for $15 \mathrm{~min}$ in tap water.

Assays for committed nerve precursors. Committed nerve precursors were assayed according to the procedure of Venugopal and David (1981a) except that explants were incubated for $18 \mathrm{hr}$ instead of $12 \mathrm{hr}$. This longer incubation permitted more effective recovery of committed precursors. To prepare explants, heads were removed from hydra below the tentacle ring and the distal fifth of the body column was excised. Such isolated pieces contain about 1500-1600 epithelial cells. Explants were maintained in closed petri dishes at a density of 15 pieces per $10 \mathrm{ml}$ of hydra medium. In all experiments 10-20 explants were analyzed per sample.
In some experiments, the explantation procedure was replaced by injury (see Results). Animals were injured by three well-spaced transverse cuts per body column. The injured animals were maintained in closed petri dishes at a density of 10 animals per $10 \mathrm{ml}$ of hydra medium; in all experiments 5-8 animals were analyzed per sample.

The ratio of nerve cells to epithelial cells $(\mathrm{Nv} / \mathrm{Epi})$ in whole hydra is commonly $0.11-0.12$; the Nv/Epi ratio in explants of the gastric region is commonly 0.08-0.09. These values form the baseline for most of the experiments reported here. However, there is some long-term variation in these baseline levels depending on the condition of the culture.

Preparation of crude extract. About 1000 hydra were sonicated in $3 \mathrm{ml}$ hydra medium under ice cooling for 2-4 min with a Braun Labasonic 1510 ultrasonicator at $50 \mathrm{~W}$. The absorption at $280 \mathrm{~nm}$ was used to estimate the concentration of the crude extract. An absorbance of $0.12 \mathrm{OD}_{280 \mathrm{~nm}}$ corresponds to the extract of one hydra (without buds) per milliliter (Schaller, 1973).

Preparation of methanol extract. Crude extract was prepared from about 1000 animals by sonication in 10 $\mathrm{ml}$ hydra medium. After addition of $10 \mathrm{ml}$ methanol, the extract was shaken vigorously and then centrifuged at $5000 \mathrm{~g}$ (6500 rpm on Sorvall SS 34 rotor) for $15 \mathrm{~min}$ at $0^{\circ} \mathrm{C}$. The supernatant was decanted and saved. The pellet was resuspended in $10 \mathrm{ml}$ methanol, shaken again, and centrifuged at $5000 \mathrm{~g}$ for $15 \mathrm{~min}$. The extraction procedure was repeated three times. All supernatants were combined and centrifuged again at $5000 \mathrm{~g}$ for $15 \mathrm{~min}$ to remove residual precipitated material. The final supernatant was extracted three times with $10 \mathrm{ml}$ petroleum ether $\left(\right.$ bp $\left.50-60^{\circ} \mathrm{C}\right)$. The methanol extract was concentrated to $2 \mathrm{ml}$ on a rotary evaporator and then made up to a final volume of $10 \mathrm{ml}$ (i.e., the starting volume) and stored at $-20^{\circ} \mathrm{C}$. The concentration (hydra $/ \mathrm{ml}$ ) of the extract was determined from the absorbance $(280 \mathrm{~nm})$ of the initial sonicate assuming $0.12 \mathrm{OD}_{280 \mathrm{~nm}}$ per hydra (Schaller, 1973).

Hydra head activator. Hydra head activator [pGluPro-Pro-Gly-Gly-Ser-Lys-Val-Ile-Leu-Phe (Schaller and Bodenmüller, 1981)] was synthesized by BACHEM (Switzerland). It was stabilized in its monomeric form by treatment with $\left(\mathrm{NH}_{4}\right)_{2} \mathrm{SO}_{4}$. One nanomole of the synthetic peptide was solubilized in $50 \mu$ distilled water, mixed with $50 \mu \mathrm{l} 3 \mathrm{M}\left(\mathrm{NH}_{4}\right)_{2} \mathrm{SO}_{4}$ and thereafter with 10 $\mathrm{ml} \mathrm{1 \%} \mathrm{BSA} \mathrm{(in} \mathrm{0.1} \mathrm{M} \mathrm{PBS,} \mathrm{pH} \mathrm{7.4).} \mathrm{This} \mathrm{stock} \mathrm{solution}$ was stored at $-20^{\circ} \mathrm{C}$ in $0.1-\mathrm{ml}$ aliquots. Aliquots were thawed and diluted to the required concentration with hydra medium.

Radioimmunoassay for hydra head activator. Radioimmunoassays (RIA) for head activator were performed according to the method of Bodenmüller and 
Zachmann (1983). The incubation buffer for the RIA was $40 \mathrm{mM}$ sodium phosphate ( $\mathrm{pH} 7.4)$ containing $2.5 \mathrm{mg} /$ $\mathrm{ml}$ bovine serum albumin, $6 \mathrm{mg} / \mathrm{ml} \mathrm{NaCl}$, and $1 \mathrm{mg} / \mathrm{ml}$ sodium azide. Peptide standards or extracts of unknown head activator concentration were incubated at $4^{\circ} \mathrm{C}$ for $4 \mathrm{hr}$ with antiserum $12.4(1: 10,000)$ in a total volume of $500 \mu \mathrm{l}$. After $4 \mathrm{hr}$ the radioactive tracer $\left(\sim 4000 \mathrm{cpm}{ }^{125} \mathrm{I}\right.$ Tyr ${ }^{11}$-head activator) was added and incubated overnight. The antigen-antibody complex was precipitated by addition of $200 \mu$ l bovine $\gamma$-globulin (1\%) and $1.5 \mathrm{ml}$ $20 \%$ polyethylene glycol 6000 containing $0.03 \%$ Triton $\mathrm{X}-100$ followed by centrifugation $\left(30 \mathrm{~min}, 4^{\circ} \mathrm{C}\right)$ at $2000 \mathrm{~g}$. The pellets were counted in a Phillips gamma counter.

\section{RESULTS}

Appearance of newly differentiated nerve cells in explanted pieces of hydra tissue after treatment with crude extract. In order to identify signals inducing nerve commitment, we tested the influence of crude extract on whole hydra. To assay for committed nerve cells, small pieces of tissue were explanted from the treated animals, incubated for $18 \mathrm{hr}$ to permit differentiation of committed cells, and scored for nerve cells (see Materials and Methods). The results in Fig. 1 demonstrate an increase in the number of nerve cells (expressed as the ratio of nerve cells to epithelial cells: Nv/Epi) in animals treated with increasing amounts of crude extract. The maximum increase represents a doubling of the Nv/Epi ratio from 0.09 to 0.18 and occurs at a concentration corresponding to the extract of $2.0 \mathrm{hydra} / \mathrm{ml}$. A further increase in the extract concentration resulted in a decrease in the Nv/Epi ratio down to control levels.

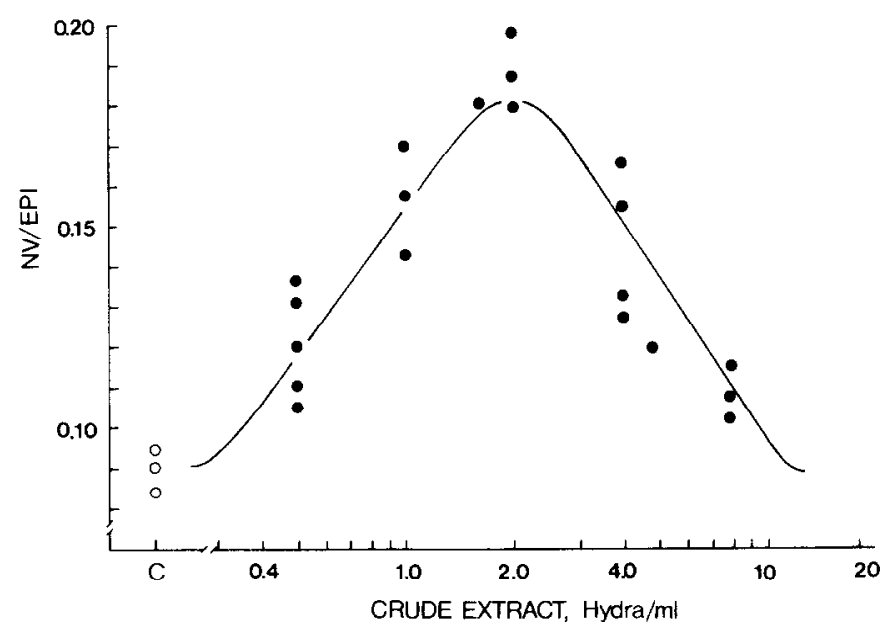

Fig. 1. Effect of crude extract on nerve cell differentiation. Whole hydra were treated with crude extract for $18 \mathrm{hr}$. Explants were prepared, incubated for $18 \mathrm{hr}$, macerated, and scored for nerve cells (Nv) and epithelial cells (Epi). Each point represents an independent experiment. Untreated control hydra (O); crude extract-treated hydra ( $)$.
The change in the Nv/Epi ratio is due to a change in the number of nerve cells per explant since the number of epithelial cells remains essentially constant during the 18-hr incubation. Furthermore, the increase occurs in pieces explanted from all parts of the body column of treated animals (Table 1). Since such animals contain about 9000 epithelial cells, the total increase in newly differentiated nerve cells corresponds to about 800 cells per animal. This increase is much higher than the increase due to normal growth (David and Gierer, 1974) and represents differentiation of cells newly committed as a result of crude extract treatment.

Identification of the factor causing nerve commitment. Because it appeared likely that the active factor(s) in the crude extract was similar to those observed previously by Schaller (1976b), we began our purification with a methanol extraction to isolate peptides and other low molecular weight molecules. Essentially all the biological activity present in crude extract was recovered in the methanol phase (data not shown). Figure 2 demonstrates the activity of increasing concentrations of methanol extract in the nerve cell commitment assay. Maximal activity occurs at a concentration corresponding to the extract of 0.5 hydra $/ \mathrm{ml}$. By comparison with crude extract (Fig. 1), methanol extract is about two times more active than crude extract. At present it is not clear whether this enhancement of the activity is due to removal of an inhibitor of nerve cell commitment during the methanol extraction or to removal of enzymes which destroy the active factor(s). The enhancement is consistently observed following methanol extraction.

The range over which methanol extract stimulates nerve cell commitment is narrow: concentrations higher than the extract of 0.5 hydra $/ \mathrm{ml}$ lead to a decrease in the ratio Nv/Epi. Thus, although methanol extract is significantly more active than crude extract, it still appears to contain inhibitory and/or toxic components which prevent nerve cell commitment.

In view of the fact that the head activator enhances nerve cell differentiation during head regeneration (Schaller, 1976b) and that the head activator can be extracted with methanol, it appeared likely that at least one of the factors causing nerve cell commitment might be the head activator. To test this we attempted to remove the nerve cell committing activity from methanol extract with procedures which remove head activator.

1. The head activator is retained on Sep-Pak $\mathrm{C}_{18}$ columns (Schaller et al., 1984). Table 2 indicates that the activity causing nerve cell commitment is removed by chromatography on Sep-Pak $\mathrm{C}_{18}$.

2 . The head activator is specifically bound by a polyclonal antibody (Bodenmüller and Zachmann, 1983). Incubation of methanol extract for $24 \mathrm{hr}$ with this antibody 
TABLE 1

Effect of Crude Extract on Nerve Cell Commitment in Different Regions of tile Body Colum

\begin{tabular}{lcc}
\hline Assayed region & $\begin{array}{c}\text { Nerve cell density } \\
(\mathrm{Nv} / \mathrm{Epi})\end{array}$ & $\begin{array}{c}\text { Increase in Nv/Epi } \\
\left(t_{18}-t_{0}\right)\end{array}$ \\
\hline Head & 0.251 & +0.06 \\
Upper gastric region & 0.097 & +0.08 \\
Lower gastric region & 0.080 & +0.07 \\
Peduncle/foot & 0.255 & +0.10 \\
\hline
\end{tabular}

Note. Budless hydra were treated for $18 \mathrm{hr}$ with crude extract ( 1 hydra $/ \mathrm{ml}$ ). Treated animals were then cut into four sections and macerated directly $\left(t_{0}\right)$ or incubated for $18 \mathrm{hr}$ before maceration $\left(t_{18}\right)$.

removed $90 \%$ of the activity causing nerve cell commitment (Table 2). Treatment of hydra with anti-head activator antibody alone had no effect on nerve cell differentiation (Table 2).

The results above indicate that head activator or a closely related substance is the active component in methanol extract stimulating nerve commitment.

Synthetic head activator causes nerve cell commitment. Recently, Schaller and Bodenmüller (1981) determined the structure of the head activator. It is an 11-aminoacid peptide (pGlu-Pro-Pro-Gly-Gly-Ser-Lys-Val-IleLeu-Phe) which can now be prepared synthetically. We have tested synthetic head activator over a range of

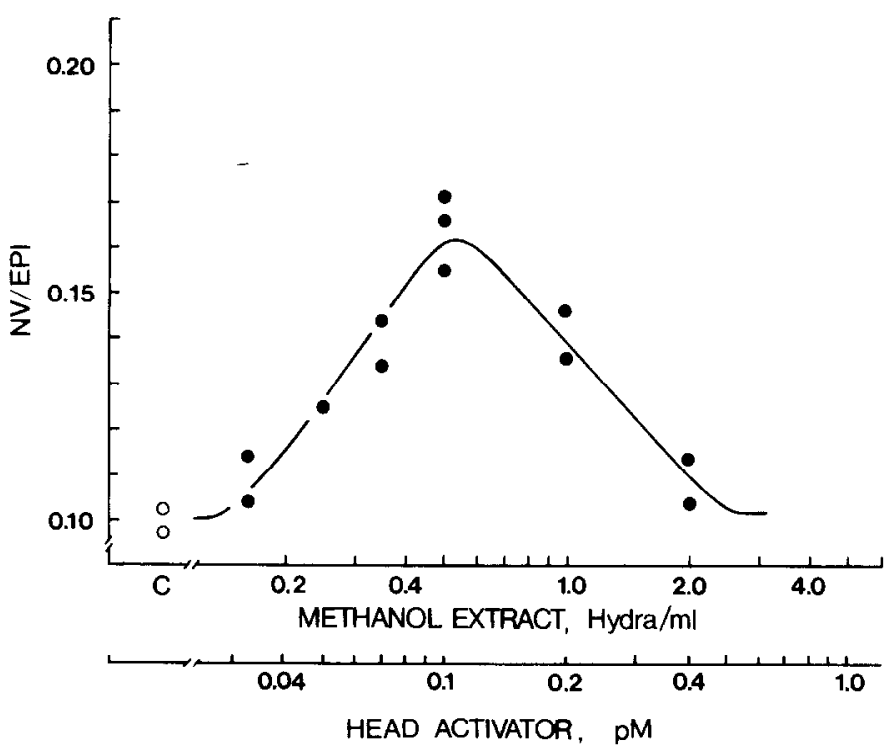

FIG. 2. Effect of methanol extract on nerve cell differentiation. Whole hydra were treated with methanol extract $(18 \mathrm{hr})$. Following treatment the animals were injured (see Materials and Methods), incubated for $18 \mathrm{hr}$, macerated, and scored for nerve cells (Nv) and epithelial cells (Epi). Each point represents an independent experiment. Untreated control hydra (O); methanol extract-treated hydra (๑). The lower abscissa is based on a radioimmunoassay of the head activator concentration in the methanol extract (see Materials and Methods).
TABLE 2

Removal of Nerve Cell Committing Activity FROM METHANOL EXTRACTS

\begin{tabular}{lc}
\hline \multicolumn{1}{c}{ Treatment } & Nv/Epi \\
\hline Hydra medium & 0.09 \\
Methanol extract & 0.18 \\
Methanol extract/Sep-Pak & 0.11 \\
Methanol extract/anti-head activator antibody & 0.10 \\
Anti-HA antibody & 0.09 \\
\hline
\end{tabular}

Note. Budless hydra were treated for $18 \mathrm{hr}$ as shown. Following treatment the animals were injured and incubated for $18 \mathrm{hr}$ to induce differentiation of committed nerve precursors (see Results and Table 4). Samples were macerated and scored for nerve and epithelial cells. Methanol extract: 0.5 hydra $/ \mathrm{ml}$.

Methanol extract/Sep-Pak: $20 \mathrm{ml}$ methanol extract $(0.5 \mathrm{hydra} / \mathrm{ml})$ was applied to a Sep-Pak $\mathrm{C}_{18}$ cartridge (equilibrated with $20 \%$ methanol). Under these conditions head activator is retained by the resin (Schaller et al., 1984). The eluate was used.

Methanol extract/anti-head activator antibody: $40 \mu \mathrm{l}$ of methanol extract (containing 0.007 pmole head activator) was added to $4 \mathrm{ml}$ of a 1/1000 dilution of anti-head activator antibody in PBS. The mixture was incubated overnight at $4^{\circ} \mathrm{C}$, diluted $1 / 20$ to a final extract concentration of $0.5 \mathrm{hydra} / \mathrm{ml}$ in hydra medium, and used directly.

Anti-head activator antibody: Anti-head activator antibody was diluted $1 / 1000$ in PBS, then diluted $1 / 20$ in hydra medium and used directly.

concentrations for its ability to cause nerve cell commitment. The results in Fig. 3 indicate that head activator at a concentration of $10^{-11}-10^{-13} \mathrm{M}$ causes nerve cell commitment in our assay system. With increasing concentrations of head activator the ratio of Nv/Epi increased from a baseline value of 0.12 (untreated controls) to a value of 0.19 . In contrast to the findings with methanol extract the head activator is active over a 100 -fold concentration range.

Concentration of head activator in methanol extracts. To test whether the effect of methanol extract on nerve cell commitment could be accounted for by head activator, we used a radioimmunoassay to determine the concentration of head activator in such extracts. For example, the extract used for the experiments in Fig. 2 contained a concentration of $0.17 \mathrm{pmole} / \mathrm{ml}$ head activator. Since this preparation contained the extract of $840 \mathrm{hydra} / \mathrm{ml}$, the amount of head activator per hydra is 0.2 fmole. Based on this determination a second abscissa has been added to Fig. 2 indicating the concentration of head activator in the extract.

Comparison of the results in Figs. 2 and 3 indicates that methanol extract containing $10^{-13} M$ head activator yields essentially the same level of nerve commitment as $10^{-13} M$ synthetic head activator. Were additional factors causing nerve cell commitment present in methanol extract, then the effectiveness of methanol extract would be greater for a given concentration of head ac- 


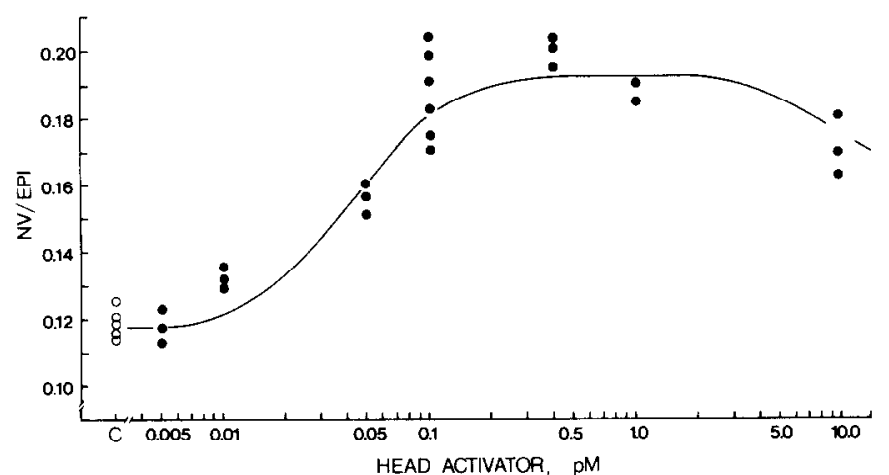

FIG. 3. Effect of synthetic head activator on nerve cell differentiation. Whole hydra were treated with synthetic head activator (BACHEM, Switzerland) for $18 \mathrm{hr}$. Treated animals were injured (see Materials and Methods), incubated for $18 \mathrm{hr}$, macerated, and scored for nerve cells (Nv) and epithelial cells (Epi). Each point represents an independent experiment. Untreated control hydra $(O)$; head activatortreated hydra $(\bullet)$

tivator and thus the curve in Fig. 2 would be displaced to the left. Since the curves in Figs. 2 and 3 are almost identical when normalized to head activator content, it appears that head activator is the principal active component in methanol extract. However, the presence of low levels of other factors cannot be excluded given the errors in the measurements.

Individual cells are committed by head activator treatment. To test whether committed nerve precursors can express their committed state independent of the tissue in which they reside, we dissociated the tissue following head activator treatment and assayed the ability of single cells to differentiate into nerves when transferred to a culture system consisting of reaggregated hydra cells (Gierer et al., 1972). Committed nerve precursors have been shown to complete nerve differentiation in this system (Venugopal and David, 1981a; Yaross et al., 1982). To distinguish between already existing and newly differentiated nerve cells, treated hydra were prelabeled with $\left[{ }^{3} \mathrm{H}\right]$ thymidine. The results in Table 3 indicate a fivefold increase in the number of newly differentiated (labeled) nerve cells from tissue which had been treated for $12 \mathrm{hr}$ with head activator prior to dissociation. Mixing unlabeled head activator-treated cells with labeled control cells did not stimulate formation of labeled nerve cells from the control tissue. Hence, differentiation of labeled nerve cells from head activator-treated tissue is not simply due to the presence of head activator tissue in the aggregates. Rather, the result indicates that nerve cell commitment caused by head activator treatment is a cell autonomous property.

The head activator has been shown to stimulate interstitial cell mitoses in hydra (Schaller, 1976a). Hence, the increase in labeled nerve cells observed in Table 3 could be due to an increased number of interstitial cells in $\mathrm{S}$ phase as a result of mitogenic stimulation. This is certainly partially true. However, labeled nerve cells can also be induced in animals labeled with $\left[{ }^{3} \mathrm{H}\right]$ thymidine prior to head activator treatment (unpublished results). Thus, it is clear that cells in $\mathrm{S}$ phase do respond to head activator. Furthermore, results in the accompanying report (Holstein and David, 1986) indicate that head activator causes commitment in S phase.

Effect of explantation on nerve cell differentiation. The marked increase in committed nerve precursors, as assayed by the explantation technique, after treatment with hydra extracts leads one to expect an increase in newly differentiated nerve cells in whole animals treated with hydra extracts. However, such an increase is not observed. Table 4 shows that whole animals, which were incubated for $18 \mathrm{hr}$ in methanol extract and thereafter for $18 \mathrm{hr}$ in hydra medium, did not differentiate new nerve cells. By comparison, explants from hydra treated with methanol extract showed a significant increase in new nerve cells.

The surprising fact that tissue explantation is necessary to ensure nerve cell differentiation after treatment with methanol extract raises questions about the nature of the signal caused by the explantation procedure. There appear to be two possible explanations: (1) explantation removes an inhibitory effect emanating from head or foot tissue or (2) injury of the tissue during explantation releases a signal stimulating differentiation of committed precursors. These two possibilities can be distinguished by simply injuring tissue rather than explanting it and scoring the differentiation of committed nerve precursors.

Following a standard 18-hr treatment with methanol extract, hydra were injured by three well-spaced trans-

TABLE 3

Differentiation of COMMITTED $\left[{ }^{3} \mathrm{H}\right]$ Thymidine-LABELED NeRve Cells in REAGgRegateS

\begin{tabular}{lrr}
\hline & \multicolumn{2}{c}{ NV*/aggregate } \\
\cline { 2 - 3 } & $48 \mathrm{hr}$ & $72 \mathrm{hr}$ \\
\hline Head activator* $^{*}$ & $61 \pm 10$ & $71 \pm 9$ \\
Control $^{*}$ & $17 \pm 5$ & $\mathbf{1 4} \pm 13$ \\
Control $^{*} /$ head activator & $9 \pm 4$ & $22 \pm 9$ \\
\hline
\end{tabular}

Note. Fifty hydra were treated for $12 \mathrm{hr}$ with head activator $\left(10^{-13}\right.$ $M$ ) or hydra medium (control), dissociated in cell culture medium, and reaggregated with a threefold excess of untreated hydra cells (Gierer et al., 1972). Each aggregate contained the equivalent of cells from one labeled hydra. One hour prior to dissociation treated animals were labeled with $\left[{ }^{3} \mathrm{H}\right]$ thymidine (asterisk). One group of head activatortreated animals was not labeled. Aggregates were macerated in groups of 10 after 48 and $72 \mathrm{hr}$ incubation and scored for labeled nerve cells $\left(\mathrm{Nv}^{*}\right)$ by autoradiography. 
TABLE 4

Characterization of the InJURy Signal

\begin{tabular}{|c|c|c|}
\hline First treatment & Second treatment & $\mathrm{Nv} / \mathrm{Ep}$ \\
\hline Hydra medium & Explant & 0.11 \\
\hline Methanol extract $(18 \mathrm{hr})$ & Hydra medium (18 hr) & 0.11 \\
\hline Methanol extract $(18 \mathrm{hr})$ & Explant (18 hr) & 0.19 \\
\hline Methanol extract $(18 \mathrm{hr})$ & Injury $(18 \mathrm{hr})$ & 0.17 \\
\hline Injury (18 hr) & Explant (18 hr) & 0.10 \\
\hline Hydra medium & Injury & 0.12 \\
\hline Methanol extract $(18 \mathrm{hr})$ & $\begin{array}{l}\text { Methanol extract }(18 \mathrm{hr}) \text {, } \\
1.0 \mathrm{hydra} / \mathrm{ml}\end{array}$ & 0.15 \\
\hline Methanol extract $(18 \mathrm{hr})$ & $\begin{array}{l}\text { Methanol extract }(18 \mathrm{hr}) \text {, } \\
2.0 \mathrm{hydra} / \mathrm{ml}\end{array}$ & 0.17 \\
\hline Methanol extract $(18 \mathrm{hr})$ & $\begin{array}{l}\text { Head activator }(18 \mathrm{hr}) \\
10^{-12} M\end{array}$ & 0.12 \\
\hline Methanol extract $(18 \mathrm{hr})$ & $\begin{array}{l}\text { Head activator }(18 \mathrm{hr}) \text {, } \\
\qquad 10^{-11} M\end{array}$ & 0.12 \\
\hline Methanol extract $(18 \mathrm{hr})$ & $\begin{array}{l}\text { Head activator }(18 \mathrm{hr}), \\
\qquad 10^{-10} M\end{array}$ & 0.12 \\
\hline
\end{tabular}

First treatment: Hydra were treated with methanol extract $(0.5$ hy$\mathrm{dra} / \mathrm{ml}$ ) or injured by three transverse cuts evenly spaced along the body column (Injury). The cuts healed in 1-2 min and thereafter the animals were incubated in hydra medium for $18 \mathrm{hr}$.

Second treatment: Following the first treatment animals were incubated in hydra medium, methanol extract, or head activator as shown. Explant: standard explants were excised from treated animals and incubated for $18 \mathrm{hr}$ in hydra medium. Injury: see above.

Following the second treatment, whole animals or explants were macerated and scored for Nv/Epi.

verse cuts per body column. The wound closed within 1$2 \mathrm{~min}$. The animals were then incubated for $18 \mathrm{hr}$, macerated, and scored for nerve cells. Such animals exhibit an increase in new nerve cells which is equivalent to that obtained with explantation (Table 4). Figure 4 shows quantitatively the number of cuts required to cause differentiation of committed nerve precursors. One cut placed in the middle of the body column only stimulates nerve differentiation slightly, whereas two cuts cause a large increase in the ratio of $\mathrm{Nv} / \mathrm{Epi}$. Additional cuts do not result in a further increase in the Nv/Epi ratio.

Since, after injury, committed precursor cells continue to be exposed to signals from the head and foot, these signals do not inhibit the differentiation of committed precursor cells. Thus, the essential element in the explantation procedure appears to be the release of a positive signal stimulating committed precursors to complete differentiation into nerve cells.

To investigate the nature of the injury signal, we tested methanol extracts for the presence of such an activity. Animals were treated with methanol extract to induce nerve cell commitment. Thereafter animals were treated a second time with varying concentrations of methanol extract, instead of injury, in order to induce differentiation of committed precursors. A small increase in nerve cells was obtained with methanol extract at a concentration of $1.0 \mathrm{hydra} / \mathrm{ml}$; methanol extract at a concentration of 2 hydra $/ \mathrm{ml}$ induced a significant increase in the Nv/Epi ratio (Table 4). This activity appears not to be due to head activator since pure head activator from $10^{-10}$ to $10^{-12} \mathrm{M}$ did not cause differentiation of committed precursors (Table 4).

To investigate the lifetime of the injury stimulus, animals were injured with three cuts prior to treatment with methanol extract. As shown in Table 4, injury alone does not induce nerve cell differentiation. However, injury together with methanol extract or injury up to 12 $\mathrm{hr}$ prior to treatment with methanol extract leads to differentiation of new nerve cells (Fig. 5). However, an injury stimulus $24 \mathrm{hr}$ prior to treatment with methanol extract was significantly less effective in causing differentiation of committed nerve precursors. Thus the injury stimulus appears to be long-lived.

\section{DISCUSSION}

Head activator causes nerve cell commitment. Our experiments show that treatment of hydra with a neuropeptide, the "head activator" (Schaller and Bodenmüller, 1981), converts stem cells into a state such that they differentiate into nerve cells in explants. We define these cells as committed nerve precursors. The committed state is an autonomous property of cells since it is ex-

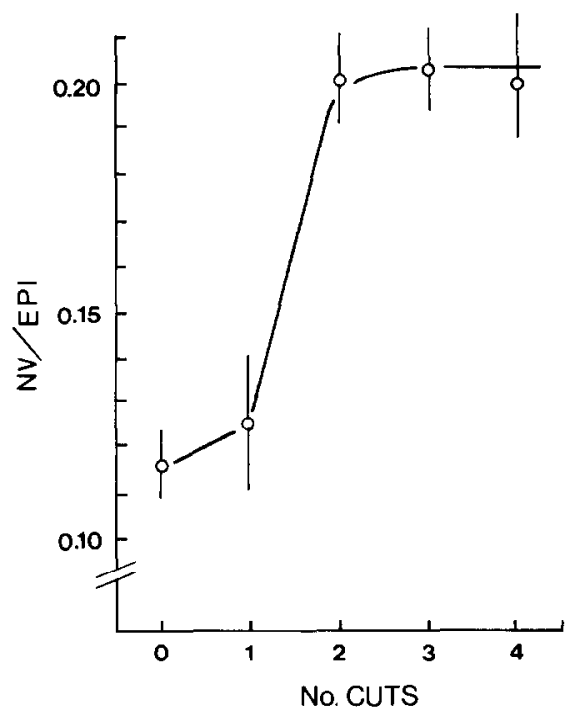

F'IG. 4. Effect of injury on differentiation of nerve cells in hydra treated with methanol extract. Hydra were treated with methanol extract $(0.5 \mathrm{hydra} / \mathrm{ml} ; 18 \mathrm{hr})$. Transverse cuts were then made in the body column: single cuts were made in the middle of the body column; multiple cuts were evenly spaced along the body column. After incubation for $18 \mathrm{hr}$, animals were macerated and scored for nerve cells (Nv) and epithelial cells (Epi). 


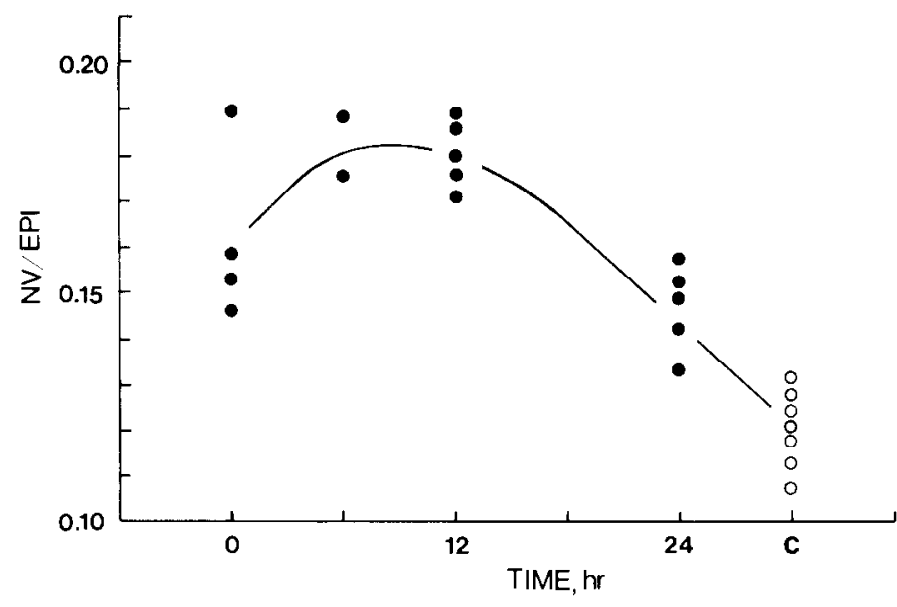

FIG. 5. Determination of lifetime of the injury signal. Hydra were injured with three transverse cuts and incubated from 0 to $24 \mathrm{hr}$ in hydra medium before addition of methanol extract $(0.5 \mathrm{hydra} / \mathrm{ml})$ for $18 \mathrm{hr}$. At the end of extract treatment, animals were macerated and scored for nerve cells (Nv) and epithelial cells (Epi). Abscissa: time (hr) between injury and addition of methanol extract. Each point represents an independent experiment. Injured and methanol extracttreated hydra (-); uninjured and untreated control hydra $(O)$.

pressed following transplantation of single cells into a feeder layer culture system ('Table 3).

We use the term nerve commitment advisedly, since it implicates the idea that a multipotent cell is affected in its differentiation fate. Commitment appears to be the appropriate term in this case. Cell cloning experiments have demonstrated the presence of a multipotent stem cell precursor to both nerve cells and nematocytes in hydra (David and Murphy, 1977). No evidence for stem cells with limited differentiation potential, e.g., for nerve cells, was found in these experiments. Hence there is no evidence for the idea that committed nerve and nematocyte precursors are maintained as stable stem cell lineages with limited differentiation potential. However, the possibility that stem cells with limited self-renewal capacity and limited differentiation potential are created continuously in hydra cannot be excluded since such cells would probably not have been detected in the cloning experiments.

If only multipotent stem cells exist in hydra, then increased nerve cell differentiation stimulated by head activator treatment must occur at the expense of these multipotent cells (as well as other products of these cells). Evidence for such a negative effect of head activator on stem cell self-renewal or nematocyte differentiation would be clear evidence that head activator interacts with uncommitted stem cells to cause nerve cell commitment. There is one report that head activator treatment reduces nematocyte differentiation (Schaller, 1976b) and preliminary experiments in our laboratory confirm this observation. These experiments also indi- cate that head activator treatment markedly slows the growth of the stem cell population in hydra (Holstein et al., in preparation). Such results are not consistent with the idea that head activator stimulates the differentiation of a committed precursor since in this case head activator treatment would not be expected to affect either stem cell self-renewal or nematocyte differentiation. Hence, the evidence presently available favors the conclusion that head activator directly interacts with multipotent stem cells to cause nerve cell commitment.

Head activator causes nerve cell commitment at a concentration of $10^{-11}-10^{-13} M$ (Fig. 3). Head activator appears to be the principal active component in hydra extracts since (1) head activator accounts for most or all of the nerve cell committing activity in methanol extracts (Figs. 2 and 3) and (2) treatment of methanol extracts with an antibody specitic for head activator removes the biological activity (Table 2 ).

Fraction of stem cell population responding to head activator. The fraction of stem cells committed to nerve cell differentiation by head activator treatment can be estimated from the ratio of newly committed nerve cells to stem cells. Treatment with $10^{-13} M$ head activator for $18 \mathrm{hr}$ causes a maximum increase of about 300 committed nerve precursors per animal $(0.07 \mathrm{Nv} / \mathrm{Epi} \times 9000 \mathrm{Epi} /$ animal $\times 1$ precursor $/ 2$ nerve cells). Such animals have about 3000 large interstitial cells $(1 \mathrm{~s}+2 \mathrm{~s}$; data not shown) of which about 1200 are stem cells (David and Gierer, 1974). Assuming that commitment occurs at a unique point in the cell cycle (Berking, 1979; Venugopal and David, 1981c; Yaross et al., 1982) and that the stem cell cycle is 24-27 hr (Campbell and David, 1974), the results indicate that $\sim 25 \%$ of all available stem cells are committed to nerve precursors in treated animals. Since the same level of committed nerve precursors is also achieved after only $12 \mathrm{hr}$ of treatment (Holstein and David, 1986), this value of $25 \%$ is an underestimate. A more realistic estimate would appear to be $\sim 40 \%$ of available stem cells. This rate is extraordinarily high compared to the $7.0 \%$ stem cells which are committed to nerve differentiation during an 18-hr period in normal untreated animals (David and Gierer, 1974).

It is interesting to estimate the number of head activator molecules which are required to cause nerve cell commitment. Under our standard assay conditions 10 animals $(40,000$ total cells per hydra of which about 1200 are stem cells; see above) are incubated for $18 \mathrm{hr}$ in $10^{-18}$ $M$ head activator (corresponding to $6 \times 10^{8}$ molecules per assay). If all cells bind head activator and all the head activator is bound during the incubation, then each cell would bind 1500 head activator molecules. If only stem cells bind head activator, then each stem cell would bind 50,000 molecules. Such estimates are of necessity approximate since at present we have no information 
about the number, localization, or binding properties of head activator receptors. However, they suggest that relatively few molecules are likely to be sufficient to cause nerve cell commitment.

Assuming that head activator is the principal signal regulating nerve cell commitment in vivo, it is possible to estimate the in vivo distribution of free (active) head activator from the pattern of nerve cell commitment in whole animals (Venugopal and David, 1981c). This pattern of nerve cell commitment has high levels at both head and foot ends and relatively low levels throughout most of the body column. The transition from high levels at the ends to low levels in the body column appears to be quite sharp and is best described as a step. While the high levels in the head are easily understood as local high levels of free head activator, it seems likely that the high levels in the foot are due to another molecule, the foot activator (Grimmelikhuijzen and Schaller, 1977). It is interesting to note that the concentration profile of head activator along the body column inferred from the pattern of nerve cell commitment is very similar to the pattern of head "activation" postulated by MacWilliams' (1982) model of hydra morphogenesis.

Committed nerve precursors require a second signal to differentiate. A surprising result of the present study was that the differentiation of committed nerve precursors occurred only in explants or in animals which were injured after treatment with extracts (Table 4). Differentiation of nerve cells did not occur in hydra treated with extract but not injured or in hydra which were injured but not treated with extract. Further results discussed in the accompanying paper (Holstein and David, 1986) indicate that committed nerve precursors are blocked in G1 phase of the cell cycle. Injury or explantation relieves this block.

The nature of the injury stimulus is at present unclear. It does not appear to be due to depletion of differentiation inhibitors at the site of wounding since it is a long-lived effect whereas wounds close rapidly. In particular inhibitory molecules emanating from head and foot tissue, which are known to leak at cut surfaces (Kemmner and Schaller, 1984), would be rapidly replenished after the wound heals. Thus it appears more likely that injury causes the release of a stimulatory signal into the tissue. This signal appears to be present in methanol extracts (Table 4). Since the head activator is known to be released at cut surfaces (Schaller, 1976c), it seemed possible that the injury stimulus was head activator. However, head activator cannot replace the injury stimulus at any concentration from $10^{-10}$ to $10^{-12} M$ (Table 4). Furthermore, the injury stimulus itself does not lead to commitment of nerve precursors (Table 4) as would be expected if significant amounts of head activator were released at the site of injury. Thus, it does not appear likely that the injury stimulus is due to the local release of head activator. The molecular nature of the injury signal is presently unknown. However, it is interesting to note that treatment of hydra with $10^{-5} M$ dibutyryl cyclic AMP and $10^{-3} M$ theophylline can mimic the injury stimulus (unpublished observations).

The most intriguing aspect of the injury stimulus is the possibility that it may be an experimental procedure which mimics a normal control mechanism. Several years ago Berking (1980) demonstrated the presence of committed nerve precursors in the budding region. These cells migrate to the site of the prospective bud prior to bud evagination. Five hours after the start of evagination they differentiate synchronously into nerve cells. Thus, the signal initiating bud evagination is similar, in its effect on nerve differentiation, to the injury stimulus. Perhaps they are the same signal.

Were the budding signal and the injury signal identical, then the budding signal should also be long-lived and buds should not exhibit the block to nerve differentiation which is characteristic of adult tissue. This is actually true. Head activator treatment of very young buds, i.e., buds which were collected within $12 \mathrm{hr}$ after detaching from the mother animal, causes nerve cell differentiation without an injury stimulus (data not shown). By the time buds are 1-2 days old this property disappears and injury is required to obtain differentiation of committed nerve precursors. This fact also provides an explanation for Schaller's (1976b) observation of enhanced nerve differentiation following head activator treatment in animals which were not injured. Since Schaller used young buds for her experiments, her observations are in accord with our results.

The authors thank Th. Bosch, H. K. MacWilliams, and C. Weijer for critically reading the manuscript. This research was supported by the Deutsche Forschungsgemeinschaft (Da 163/1-1).

\section{REFERENCES}

BERKING, S. (1979). Control of nerve formation from multipotent stem cells in hydra. J. Cell Sci. 40, 193-205.

BERKING, S. (1980). Commitment of stem cells to nerve cell precursors in preparatory bud development in Hydra. J. Embryol. Exp. Morphol 60, 373-387.

BoDE, H. R., and DAVID, C. N. (1978). Regulation of a multipotent stem cell, the interstitial cell of hydra. Prog. Biophys. Mol. Biol. 33, 189206.

Bode, H. R., Berking, S., David, C. N., Gierer, A., Schaller, H., and TRENKNER, E. (1973). Quantitative analysis of cell types during growth and morphogenesis in Hydra. Wilhelm Roux's Arch. Entwicklungsmech. Organismen 171, 269-285.

BODENMtLlER, H., and ZACHMANN, B. (1983). A radioimmunoassay for the $H y d r a$ head activator. FEBS Lett. 159, 237-240.

Campbell, R. D., and David, C. N. (1974). Cell cycle kinetics and de- 
velopment in Hydra attenuata. II. Interstitial cells. J. Cell Sci. 16, 344-358.

DAvid, C. N. (1973). A quantitative method for maceration of Hydra tissue. Wilhelm Roux's Arch. 171, 259-268.

David, C. N., and CAMprell, R. (1972). Cell cycle kinetics and development of Hydra attenuata. I. Epithelial cells. J. Cell Sci. 11, 557568.

David, C. N., and Challoner, D. (1974). Distribution of interstitial cells and differentiating nematocytes in nests in Hydra attenuata. A mer. Zool. 14, 537-542.

DAvid, C. N., and GIERER, A. (1974). Cell cycle kinetics and development of Hydra attenuata. III. Nerve and nematocyte differentiation. $J$. Cell Sci. 16, 359-375.

David, C. N., and MURPHY, S. (1977). Characterization of interstitial stem cells in Hydra by cloning. Dev. Biol. 58, 372-383.

Gierer, A., Berking, S., Bode, H., David, C. N., Flick, K., HansmanN, G., and TRENKNER, E. (1972). Regeneration of Hydra from reaggregated cells. Nature (London) 239, 98-101.

Grimmelikhuidzen, C. J. P., and Schaller, H. C. (1977). Isolation of a substance activating foot formation in hydra. Cell Diff. 6, 297-305.

Holstein, TH., and DAVID, C. N. (1986). The properties of nerve cell precursors in hydra. Dev. Biol. 115, 18-26.

KemmNer, W., and Schaller, H. C. (1984). Actions of head activator and head inhibitor during regeneration in hydra. Differentiation $\mathbf{2 6}$, 91-96.

MACWILLIAMS, H. K. (1982). Numerical simulation of hydra head regeneration using a proportion-regulating version of the Gierer Meinhardt Model. J. Theor. Biol. 99, 681-703.

SCHALLER, H. C. (1973). Isolation and characterisation of a low molecular weight substance activating head and bud formation in $\mathrm{Hy}$ dra. J. Embryol. Exp. Morphol. 29, 27-38.
SCHALLER, H. C. (1976a). Action of head activator as a growth hormone in Hydra. Cell Diff. 5, 1-11.

SCHALLER, H. C. (1976b). Action of head activator on the determination of interstitial cells in Hydra. Cell Diff. 5, 13-20.

SCHALLER, H. C. (1976c). Head regeneration in Hydra is initiated release of head activator and inhibitor. Wilhelm Roux's Arch. 180, 287-295.

SCHALLER, H. C., and BodenMtLler, H. (1981). Isolation and amino acid sequence of a morphogenetic peptide from hydra. Proc. Natl. Acad. Sci. USA 78, 7000-7004.

Schaller, H. C., and Gierer, A. (1973). Distribution of the headactivating substance in hydra and its localisation in membranous particles in nerve cells. J. Embryol. Exp. Morphol. 29, 39-52.

Schaller, H. C., Bodenmúller, H., ZaChman, B., and Schilling, E. (1984). Eur. J. Biochem. 138, 365-371.

Venugopal, G., and DAVID, C. N. (1981a). Nerve commitment in Hydra. I. Role of morphogenetic signals. Dev. Biol. 83, 353-360.

VENUGOPAL, G., and DAVID, C. N. (1981b). Nerve commitment in IIydra. II. Localization of commitment in S phase. Dev. Biol 83, 361-365.

Venugopal, G., and David, C. N. (1981c). Spatial pattern of nerve differentiation in $H y d r a$ is due to a pattern of nerve commitment. Dev. Biol. 83, 366-369.

YAROSS, M., BACA, B. A., ChOW, M. H., and Bode, H. R. (1982). Commitment of hydra interstitial cells to nerve cell differentiation occurs by late S-phase. Dev. Biol. 89, 425-436.

YAROSS, M. S., and BODE, H. R. (1978a). Regulation of interstitial cell differentiation in Hydra attenuata. III. Effects of i-cell and nerve cell densities. J. Cell Sci. 34, 1-26.

YAROSS, M. S., and BoDE, H. R. (1978b). Regulation of interstitial cell differentiation in Hydra attenuata. IV. Nerve cell commitment in head regeneration is position dependent. J. Cell Sci. 34, 27-38. 